\begin{tabular}{|c|c|c|}
\hline \hline & \begin{tabular}{c} 
International Journal of Current Research in \\
Biosciences and Plant Biology \\
\hline EXCELLENT \\
PUBLISHERS
\end{tabular} & Volume $4 \bullet$ Number 6 (June-2017) ・ ISSN: 2349-8080 (Online) \\
\hline
\end{tabular}

\title{
Effect of Sodium Arsenate on Momordica charantia L. Seeds In Vitro
}

\author{
Suman Kumar Ray and Sarmistha Sen Raychaudhuri*
}

Department of Biophysics, Molecular Biology and Bioinformatics, University of Calcutta, 92, Acharya Prafulla Chandra Road, Calcutta, 700 009, India

*Corresponding author.

\begin{tabular}{|c|c|}
\hline Abstract & Article Info \\
\hline attention because of its chronic and epidemic effects on human health. The absorption of & Keywords \\
\hline perspective the present investigation was undertaken to carry out a comparative analysis & Arsenic \\
\hline Bengal, India. Calli established in vitro were subjected to Scanning Electron Microscopy & Scanning Electron Microscopy \\
\hline $\begin{array}{l}\text { (SEM) to determine effect of arsenic on morphological alteration of calli. Seedlings grown } \\
\text { in arsenic containing media were used for Atomic Absorption Spectroscopic (AAS) }\end{array}$ & \\
\hline
\end{tabular}

\section{Introduction}

Momordica charantia (bitter melon) is a vegetable crop plant of the family Cucurbitaceae (Toyama et al., 2008; Schaefer and Renner, 2010). It is widely grown in India, China, South Asia, Africa and the Caribbean islands (Bakare et al. 2010). Momordica is a medicinally important plant species and widely used as food (Tanaka et al., 2009) in Asian countries.

Momordica has been used extensively in folk medicine as a remedy for diabetes. It is a very common herb having various medicinal properties, viz. antifungal (Santos et al., 2012), wound healing (Prasad et al., 2006), antiviral (Balasubramanian et al., 2007) and antidiabetic (Denyer et al., 2004). Bitter melon is an important nutrient rich plant composed of variety of beneficial compounds. These include vitamins, minerals and antioxidants.

Arsenic (As) is one of the toxic environmental pollutants. Arsenic has recently attracted mass attention because of its chronic and epidemic effects on human health. Arsenic contamination of ground water has been documented from time to time by various authors from many Asian countries like Bangladesh, India, China, Taiwan, Vietnam etc. (Bhattacharya et al., 2012). The Bengal basin is regarded to be the most critically affected area of As pollution. Such contamination has been reported from some districts of the state of West Bengal in India also (Chakraborti et al., 2002). This contaminated water is 
a source of irrigation and deposits As in the soil of cultivated lands (Mehrag and Rahman, 2003). The absorption of As by land plants is influenced by the concentration of As in the soil. The As concentration also depends upon the availability of soil As and the accumulation and translocation ability of a plant (Huang et al., 2006).

Large areas of Bangladesh, West Bengal and other states in India and Vietnam rely on As-contaminated groundwater for irrigation (Abedin et al., 2002). Arsenic is released into the environment in both inorganic and organic forms. Arsenic enters from soil into plants and subsequently the food chain (Rahman et al., 2007).

With this perspective the present investigation was undertaken to carry out a comparative analysis on fruit yield and in vitro efficiency of Momordica to establish callus culture from seeds collected from Burdwan town, District Purba Burdwan, West Bengal (Geographical identification $23^{\circ} 14^{\prime} 18^{\prime \prime} \mathrm{N} \quad 87^{\circ} 51^{\prime} 39^{\prime \prime} \mathrm{E}$ ) (no arsenic contamination) and Bashirhat, District North 24 parganas, West Bengal (Geographical identification $22^{\circ} 39^{\prime} 26^{\prime \prime} \mathrm{N} 88^{\circ} 53^{\prime} 39^{\prime \prime} \mathrm{E}$ ) (arsenic contaminated area).

Same study was further extended to study the effect of sodium arsenate in vitro on callus culture from seeds collected from Burdwan where no arsenic contamination was reported. Calli established in vitro were subjected to Scanning Electron Microscopy (SEM) study to determine effect of arsenic on morphological alteration of calli.

Seedlings grown in arsenic containing media were used for Atomic Absorption Spectroscopic (AAS) analysis to get a clear picture of the content of eight metals under excess arsenic treatment. Therefore the present study will clearly bring about in vitro effect of sodium arsenate on seeds of Momordica charantia procured from Burdwan, West Bengal with regard to fruit yield and callus formation efficiency. A comparative study will be included to determine the effect of variation in plant trace elemental content to detect antagonism and synergism. This effect was also illustrated by SEM pictures taken on callus culture.

\section{Materials and methods}

Seeds of Momordica charantia were procured from Burdwan and Basirhat. Plantlets were propagated by tissue culture techniques (Paul and Raychaudhuri, $2010)$. Seeds were germinated in agar $(0.9 \%)$ sucrose (3\%) media and grown into seedlings. Seeds were germinated in sodium arsenate $\left(\mathrm{Na}_{2} \mathrm{HAsO}_{4} \cdot 7 \mathrm{H}_{2} \mathrm{O}\right)$ treated agar sucrose media. Different concentration of sodium arsenate i.e. $10 \mu \mathrm{M}, 25 \mu \mathrm{M}, 50 \mu \mathrm{M}, 75 \mu \mathrm{M}, 100$ $\mu \mathrm{M}, 125 \mu \mathrm{M}, 150 \mu \mathrm{M}, 175 \mu \mathrm{M}$ and $200 \mu \mathrm{M}$ were chosen for the experiment along with control one (no treatment).

Different concentration of sodium arsenate was used to determine $\mathrm{LD}_{50}$ of sodium arsenate on $M$. charantia. Leaf discs from aseptically germinated seedlings were taken as the source of explants and used for callus induction. Murashige and Skoog (MS) medium supplemented with four combinations (Table 1) of PGRs were used for establishment of calli. All cultures were grown in proper laboratory condition (at a temperature of $22-25^{\circ} \mathrm{C}$ and a relative humidity of $55-60 \%$ under Philips fluorescent daylight tubes emitting $32 \times 108 \mathrm{~mol}$ $\mathrm{s}^{-1} \mathrm{~m}^{-2}$ for $16 / 8$-hrs duration in light/dark periods).

Table 1. Four different combinations of PGRs and sucrose.

\begin{tabular}{|c|c|c|c|c|c|}
\hline \multirow{2}{*}{ Combination } & \multicolumn{2}{|c|}{ Auxin (mg/L) } & \multicolumn{2}{|c|}{ Cytokinin (mg/L) } & \multirow{2}{*}{ Sucrose (3\%) } \\
\hline & Name & Concentration & Name & Concentration & \\
\hline $\mathrm{C} 1$ & $2,4-\mathrm{D}$ & 1.0 & KIN & 0.5 & 3 (Passage 1 ) and 2 (Passage 2 ) \\
\hline $\mathrm{C} 2$ & $2,4-\mathrm{D}$ & 0.5 & KIN & 1.0 & 2 (Passage 1 ) and 2 (Passage 2 ) \\
\hline C3 & BAP & 0.5 & NAA & 0.5 & 3 (Passage 1 ) and 3 (Passage 2) \\
\hline $\mathrm{C} 4$ & 2,4-D & 1.0 & KIN & 0.5 & 3 (Passage 1 ) and 3 (Passage 2) \\
\hline
\end{tabular}

We have determined FW and DW of the callus of established from seeds procured from Burdwan and Basirhat. FW was determined by weighing the callus grown in laboratory and after drying in hot air oven weights were measured to calculate DW.

Seedling height was determined. Roots and shoots length of the fifteen day old seedlings were measured.
AAS study was carried out using callus samples (established from seedlings) and sodium arsenate treated samples from Burdwan and Basirhat using the methods of Rahman et al. (2007). About $0.5 \mathrm{~g}$ of each sample was taken in clean dry digestion tubes and $5 \mathrm{ml}$ of concentrated $\mathrm{HNO}_{3}$ was added to it. The mixtures were allowed to stand overnight in fume hood. Following day, the digestion tubes were placed on a heating block and 
heated at $60^{\circ} \mathrm{C}$ for $2 \mathrm{hrs}$. After cooling, perchloric acid $\left(\mathrm{HClO}_{4}\right)$ was added and heated at $160^{\circ} \mathrm{C}$ for about $4-5$ hrs. Calibration was carried out using arsenate as standard (Bhattacharya et al., 2009). Eight elements namely arsenic, calcium, copper, zinc, iron, manganese, lead and cadmium were measured.

Calli were treated with different doses (above mentioned) of sodium arsenate along with control. Treated callus and control (no treatment) were fixed in $2.5 \%$ glutaraldehyde for $4 \mathrm{hrs}$. At first sample pieces were immersed in $50 \%$ alcohol for 5 mins and then in $70 \%$ alcohol for 30 minutes, thereafter in $90 \%$ and in absolute alcohol respectively for 30 mins. Then they were immersed in the mixture of different ratios of absolute alcohol and amyl acetate [3:1, 2:2 and 1:3 respectively]. In each solution the sample pieces were immersed for 30 minutes. Samples were then taken for drying using Critical Point Dryer and followed by gold coating in Sputter Gold-Coating Machine. Samples were imaged by Scanning Electron Microscopy.

\section{Results and discussion}

Seeds were germinated in the above mentioned laboratory condition. In control set all seeds were germinated. We found $\mathrm{LD}_{50}$ of sodium arsenate on Momordica charantia var. muricata was $200 \mu \mathrm{M}$. We have found that fruit yield was affected in case of seeds collected from arsenic affected zone (i.e., Basirhat). 33\% fruit yield reduction was found with respect to control one (Fig. 1).

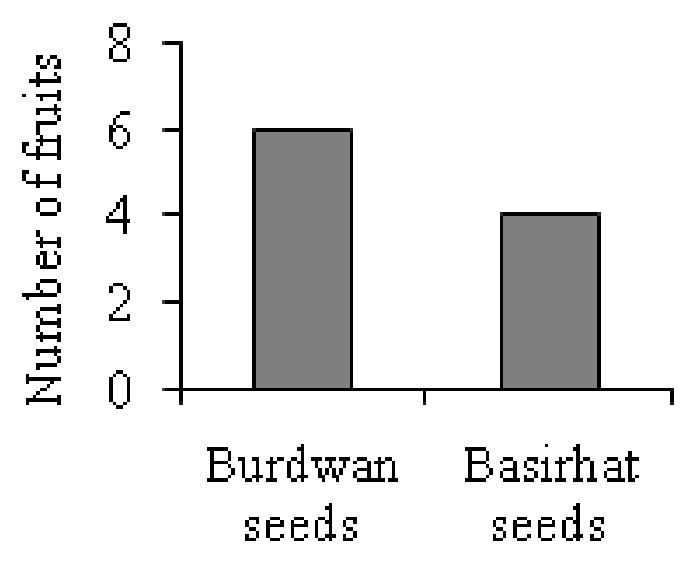

Fig 1: Histogram of number of fruits produced by M. charantia.

Seeds were germinated in the above mentioned tissue culture laboratory conditions in three different experimental sets containing ten seeds each. In control set all seeds were germinated. Germination rate was found to decrease as the concentration of sodium arsenate was increased in plant tissue culture media. Results are given in Fig. 2.

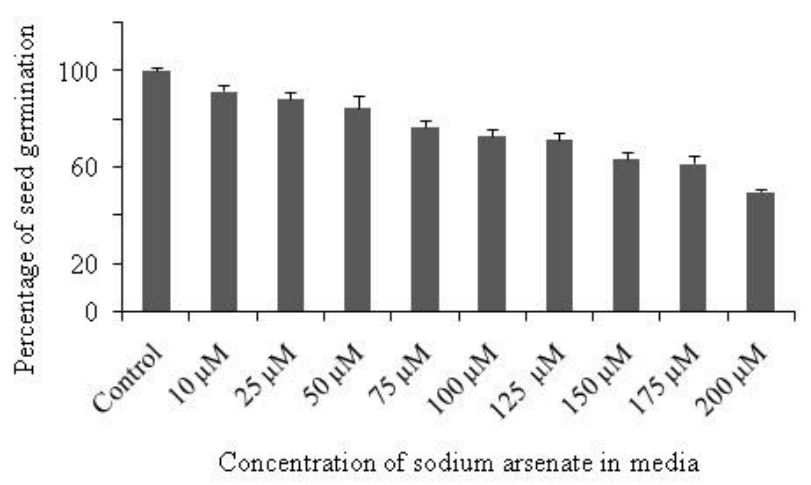

Fig 2: Percentage of seed germination in sodium arsenate treated media in vitro.

Arsenic showed a negative impact on growth of the seedlings especially on shoot length. In sodium arsenate treated seedlings maximum $40 \%$ reduction was observed at $200 \mu \mathrm{M}$ treatment as compared to untreated control plants (Fig. 3). Similar decreasing trend was observed in root length also.

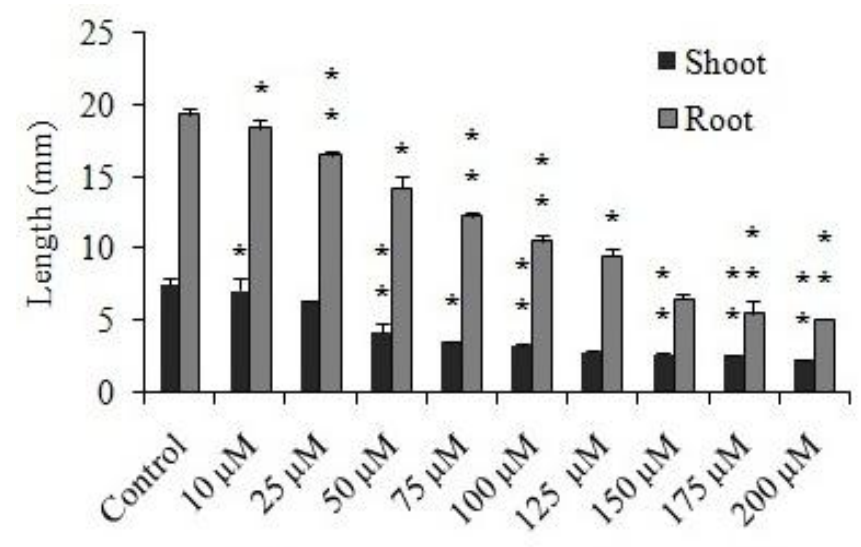

Sodium arsenate concentration in media

Fig 3: Histogram of root and shoot length of $M$. charantia grown in different concentration of sodium arsenate in media in vitro. The data were presented as the mean \pm standard error mean (SE). The experiments were performed with three replicates. The statistical analysis was carried out by using one-way analysis of variance (ANOVA). Data represent the mean \pm SE. Asterisks indicate significant differences at $p<0.05(*)$ or $p<0.01(* *)$ or $p<0.001(* * *)$ compared to respective controls.

It has been clearly observed that arsenic induced alteration in biomass (FW and DW) in our experimental 
plant system (Fig. 4). For the determination of biomass we determined FW and DW of arsenic contaminated and control samples. Highest FW and DW were recorded in case of control callus and it was $1.05 \mathrm{~g}$ and $0.21 \mathrm{~g}$ respectively. Callus induced from Basirhat seeds have shown reduced DW and FW with compare to control sample (Fig. 5).

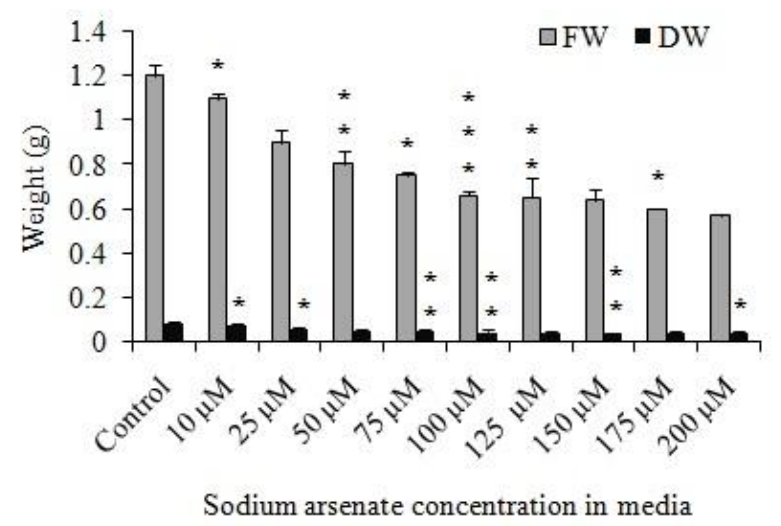

Fig 4: Histogram of DW and FW of M. charantia grown in different concentration of sodium arsenate in media in vitro.

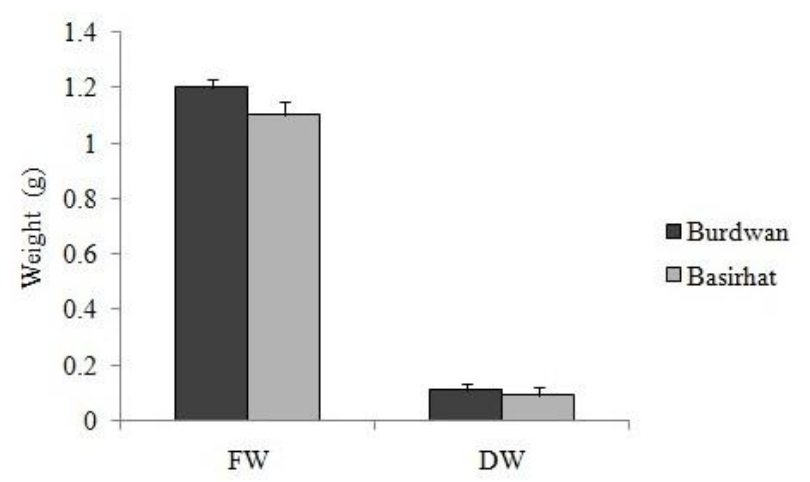

Fig 5: Histogram of DW and FW of Momordica.

Effect of different concentration of sucrose and PGRs of in vitro callus culture were studied in our present investigation. Different combination and concentration of PGRs are important for the in vitro induction of callus. In our experiment we have tried to establish best callus formation using different PGRs concentration and combination also with sucrose concentration. Manye et al. (2004) reported production of three types of callus from $M$. charantia namely green, yellow green and fragile yellow callus. We have also found greenish and yellowish type of callus which is similar to their findings. Proportion and quantity of PGRs and explants play a role in the formation of callus and the morphology of callus. The seedlings of $M$. charantia cultured in vitro for about 12-15 d were optimal for taking leaf disc as explants. Malik et al. (2007) analyzed the effect of PGRs on caulogenesis of $M$. charantia and reported callus formation from leaf explants. They used different auxin and cytokinin concentrations and combinations in MS medium.

Callus culture was established using four different combinations of PGRs and it was found that combination C4 [i.e., 2, 4-D ( $1 \mathrm{mg} / \mathrm{L}), \mathrm{KIN}(0.5 \mathrm{mg} / \mathrm{L})$ and 3\% sucrose] showed best result. Thus this combination was further used for induction of callus in both control and arsenic contaminated samples (Fig. 6).

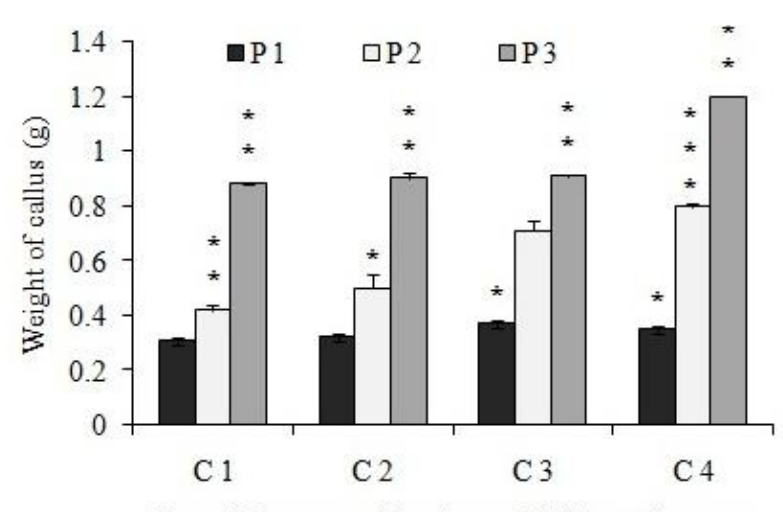

Four different combinations of PGRs and sucrose

Fig 6: Weight of callus induced by different concentration of PGR and sucrose combination.

In our experiment best result obtained from using the PGRs concentration 2-4-D (1mg/L) and kinetin $(0.5 \mathrm{mg} / \mathrm{L})$ with $3 \%$ sucrose and $0.9 \%$ agar. Sucrose is the most preferred carbon source for plant tissue culture. Researchers were found that leaf explants showed maximum callus percentage and caulogenic response when tested on MS medium supplemented with BAP, NAA, 2, 4-D and KIN. The callus produced at these PGRs concentrations including 2, 4-D, were of different texture and morphology depending upon nature of PGRs. Thiruvengadam et al. (2006) stated that MS medium containing $1.0 \mathrm{mg} / \mathrm{L} \mathrm{2,} \mathrm{4-D} \mathrm{approximately} 90 \%$ of leaf explants of $M$. charantia gave rise to a well organized calli. We have found the similar result. This concentration in 2, 4-D gave the best callus among our four combinations. Auxin plays many roles in controlling and maintaining physiological status. Auxins influence cell enlargement, bud formation and root initiation. Thus in our experiment we have also seen that concentration of auxin was important for the morphology and health of the callus. Callus culture was established using four different combinations of PGRs and it was found that combination $\mathrm{C} 4$ [i.e., 2, 4-D (1 $\mathrm{mg} / \mathrm{L}), \mathrm{KIN}(0.5 \mathrm{mg} / \mathrm{L})$ and $3 \%$ sucrose] showed best 
result. Thus this combination was further used for induction of callus in both control and arsenic contaminated samples.

Sultana and Bari Miah (2003) were used different combinations and concentrations of cytokinins and auxins on MS media for the regeneration from shoot tip. They found multiple shoot regeneration was better using BAP and NAA. In our experimental system we have given attention to make callus for the further work. Callus induction was achieved by Sultana et al. (2003) from the leaf segments on MS media containing $1.0 \mathrm{mg} / \mathrm{L} 2$, 4-D. But we got better result using 2, 4-D and KIN. In present study, we have maintained culture for three passages (21 days for each passage). According to Hartmann et al. (2002) in vitro growth are regulated by interaction and balance between PGRs supplied within a medium and growth substances induced endogenously.

After arsenic exposure, morphological changes were verified, mainly in the callus of $M$. charantia at different doses of arsenic. The damage worsened gradually as sodium arsenate dose in calli was increased (Fig. 7). From the AAS study of callus samples it was found that callus established from Burdwan sample containing no detectable arsenic and high calcium content (52.39 $\mathrm{mg} / \mathrm{kg}$ ). Callus developed from arsenic contaminated area (Basirhat) contain low calcium content and high arsenic content (Fig. 8).

Heavy metals are conventionally known as elements with high atomic mass and with metallic properties such as conductivity, stability as cations, ligand specificity etc and they are toxic in nature and cannot be processed by living organism. Metal contamination occurs due to industrial activities such as mining and smelting of metalliferous ores, electroplating, gas exhaust, energy production, fuel production, fertilizer application, pesticide application and generation of municipal waste. Metals are natural components in soil. In soil, metals are associated with free metal ions, soluble metal complexes and soil organic matter or embedded in structure of the silicate minerals.

During life processes plant not only acquire macronutrients but also acquire essential micronutrients such as $\mathrm{Fe}, \mathrm{Zn}, \mathrm{Mn}, \mathrm{Cu}$, etc. Plants have evolved very specific mechanisms to use this nutrient for translocation, physiological use and storage. Metal movement across biological membranes is mediated by proteins with transport functions or specific ion channel. (a)

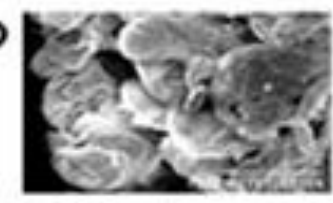

(b)

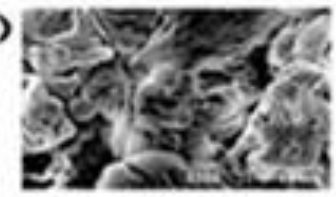

(c)

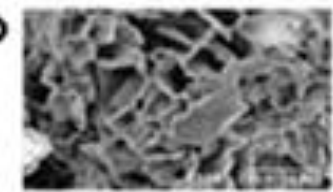

(d)

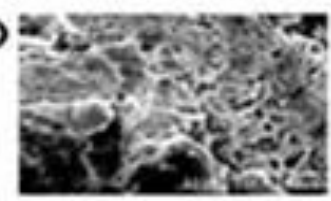

(c)

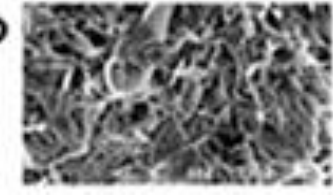

(f)

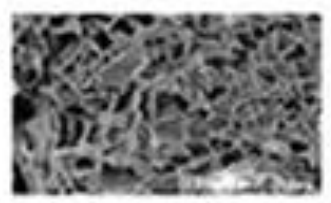

(s)

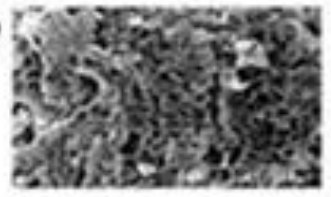

(i)

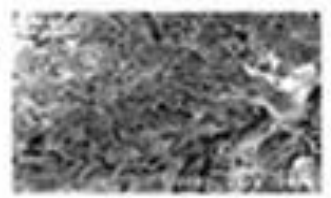

(j)

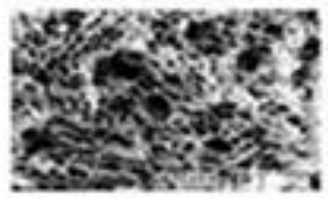

(k)

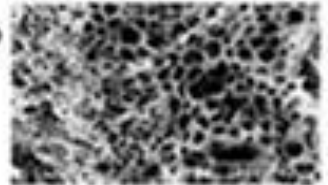

Fig 7: Scanning electron micrographs of Momordica callus. (a) control setup (b) $10 \mu \mathrm{M}$ sodium arsenate treated calli sample (c) $25 \mu \mathrm{M}$ sodium arsenate treated calli sample (d) 50 $\mu \mathrm{M}$ sodium arsenate treated calli sample (e) $75 \mu \mathrm{M}$ sodium arsenate treated calli sample (f) $100 \mu \mathrm{M}$ sodium arsenate treated calli sample (g) $125 \mu \mathrm{M}$ sodium arsenate treated calli sample (h) $150 \mu \mathrm{M}$ sodium arsenate treated calli sample and (i) $175 \mu \mathrm{M}$ sodium arsenate treated calli sample (j) $200 \mu \mathrm{M}$ sodium arsenate treated calli sample.
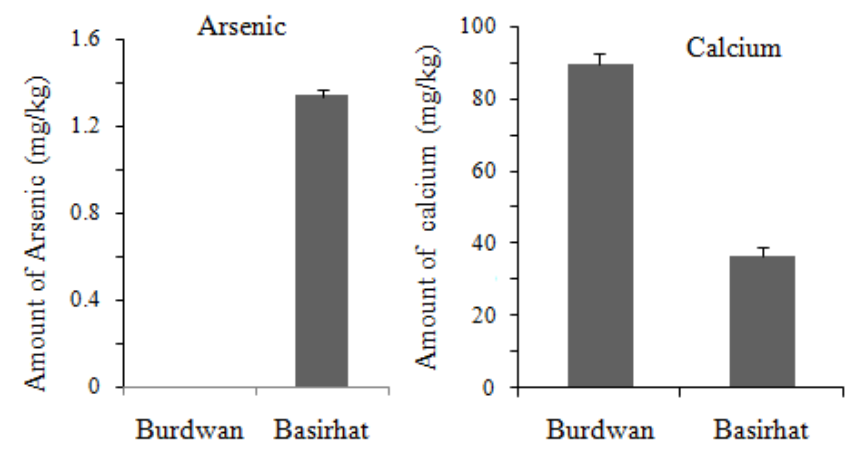

Fig 8: Concentrations of arsenic and calcium in M. charantia callus.

In plants the uptake mechanism is selective and there might be some metal-metal interaction or relation among the ions to each other. Ion uptake selectivity depends upon the structure and properties of membrane transporters. In plants metals transported from the root 
to the shoot. Movement of metal-containing sap from the root to the shoot, termed translocation, is primarily controlled by two processes: root pressure and leaf transpiration. Micronutrients such as $\mathrm{Zn}, \mathrm{Mn}, \mathrm{Fe}, \mathrm{Cu}$, etc. are essential for plant growth and development but high intracellular concentrations of these ions can be toxic. To deal with metal stress, common nonaccumulator plants have evolved several mechanisms to control the homeostasis of intracellular ions. Such mechanisms are regulation of ion influx and extrusion of intracellular ions back into the external solution etc. Metal hyperaccumulator species, capable of taking up metals in the thousands of ppm, possess specific detoxification mechanisms.

We have analysed eight different elements in our experimental plant system. Two macromolecules (nutrients required $0.02-6.0 \%$ of plant nutrient, Katalin, 2011) were namely calcium and nitrogen was measured. Nitrogen has been discussed in next chapter. Four microelements (elements required in $0.01-500 \mathrm{mg} / \mathrm{kg}$, Katalin, 2011) were measured by this techniques namely zinc, iron, manganese and copper. We also measured three elements which are known to be toxic in plants namely arsenic, lead and cadmium.

A balance of inorganic nutrients is required by plants for maximum growth and development under optimal and stressful environments. Mineral deficiencies or imbalances and depression of plant growth can result from excessive As toxicity that affects the rate of uptake and distribution of certain nutrients in plants. To reverse the negative effect of As stress, plants need to either inhibit its accumulation or enhance its tolerance capacity to As for survival. The severity of As toxicity, however, can be reduced through the optimization of these nutrients. Sufficient availability of nutrients may reduce or enhance the accumulation of a metal in plants and decrease its toxicity by inducing several physiological processes. Zinc is an important group of metal transporters family. They are thought to be involved in Cd uptake from soil into the root cell and also in transport of Cd from root-to-shoot. Enhanced root metal uptake mediated by transporters seems to be a factor necessary for hyperaccumulation. To maintain a proper physiological condition plant requires very tight homeostasis of each nutrient as well as a balanced macro and micro-nutrient composition. In this study, we further explored the relationships and interaction among some macro and micro nutrient in normal and arsenic stress condition. Iron is an integral part of chlorophyll that is involved in photosynthesis (Marschner, 1995). Chlorophyll synthesis, including the activation of several enzymes and oxidoreduction reactions requires Zn. Zinc deficiencies are associated with low total concentrations of zinc in soils featuring highly weathered parental material and low $\mathrm{pH}$ such as in tropical areas (Alloways, 2008).

Arsenic is not essential for plants (Marin et al., 1993) and has no known metabolic function. Arsenic toxicity had a varying effect on $\mathrm{Ca}, \mathrm{Zn}, \mathrm{Fe}$ and $\mathrm{Mn}$ concentration. $\mathrm{Ca}$ concentration decreased with exposure to As in Momordica. The effect of As toxicity on plant $\mathrm{Ca}$ levels is generally thought to result from reduced transpiration affecting transport of $\mathrm{Ca}$ up through the plant. Uptake of $\mathrm{Ca}$, was altered by the toxic effect of As on root functions. In addition, reduced growth limited the demand for $\mathrm{Ca}$ contributed to low uptake (Carbonell-Barrachina et al., 1994). As had little effect on $\mathrm{Ca}$, and other cations transportation to the shoot at any but the highest As exposure rate. Singh et al. (2006), reported a reduction in membrane stability with increased exposure to As. Reduced tissue Ca levels found may be related to As induced membrane stability; leaky membranes may be related to the low accumulation of other cations. Singh et al. (2006) reported membrane stability decreased with increasing exposure to As.

The concentration of calcium (Fig. 9a) in both root and shoot were decreased when the concentration of sodium arsenate in media were increased. Maximum calcium content was found in control plants and the value was $88.35 \mathrm{mg} / \mathrm{kg}$ in shoots and $84.10 \mathrm{mg} / \mathrm{kg}$ in roots. Arsenic treated seedlings showed lesser content of calcium in roots and shoot with compare to control seedlings.

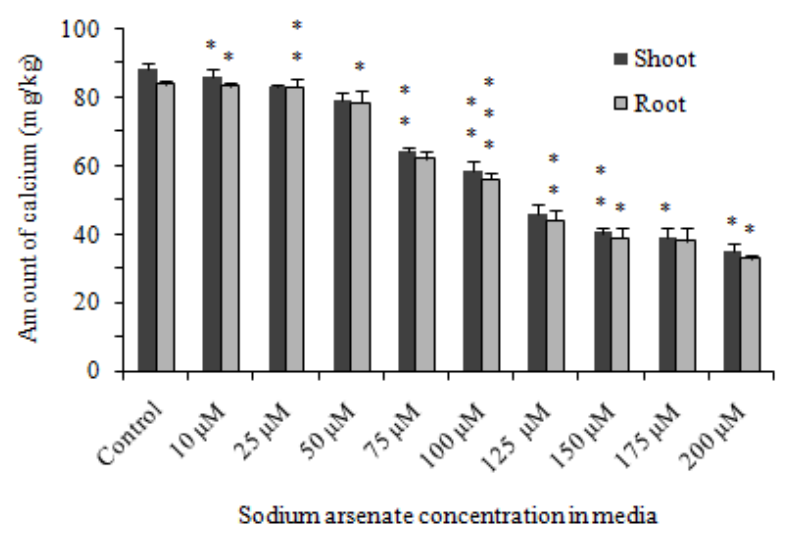

Fig 9a: Amount of calcium in M. charantia grown in different concentration of sodium arsenate in media in vitro. 
Calcium acts as a second messenger in extracellular signal transduction to transfer environmental signals (Harpner et al., 2004) and is responsible for membrane stability and wall rigidity. It has also been shown that $\mathrm{Ca}^{2+}$ influx prompted organogenesis. Calcium is a constituent of cell walls and is involved in production of new growing points and root tips. It provides elasticity and expansion of cell walls, which keeps growing points from becoming rigid and brittle. Cell death is induced under experimental conditions not only by a rise in cytoplasmic calcium but also when cytoplasmic calcium activity drops below physiologic levels (Paschen, 2003). Cellular stimulation can lead to activation of different signal transduction mechanisms, such as alterations of the cytoplasmic levels of different ions. Among the result of eight elements analysis in HG-AAS, Ca and As gave the interesting results. In the present investigation where concentration of arsenic is more found in plant samples their $\mathrm{Ca}$ concentration is decreasing. Till today there is no clear evidence was found for this type of result. We are trying to give some new finding from our experiments.

Understanding the mechanisms underlying the homeostasis of the ionome and the balance of ion acquisition has been the subject of recent research (Cuypers et al., 2013). This requires knowledge of how nutrient levels are sensed by plants and how nutrients control gene expression. The Zinc- and Iron-regulated transport Protein gene family encodes transporters for divalent metal ion nutrients (Milner et al., 2013). Studies suggest that uptake, translocation, and homeostasis of $\mathrm{Zn}, \mathrm{Fe}$, and $\mathrm{Mn}$ is controlled by the number of active transporters embedded in cell membranes. Future research will advance our understanding of the underlying physiological mechanisms enabling plant species to thrive in native habitats characterized by soils with unusual nutrient compositions.

Content of manganese (Fig. 9b) in roots was increased as the concentration of sodium arsenate was increased in media. $22 \%$ increased in manganese in roots of $200 \mu \mathrm{M}$ sodium arsenate treated samples were found when compared to untreated samples. Our data show increase in the concentrations of iron (group 8 element of periodic table) as compared to control and $200 \mu \mathrm{M}$ sodium arsenate treated samples. We found $46 \%$ increase in iron content in maximum. No significant difference were found in both root and shoot iron concentration (Fig. 9c).

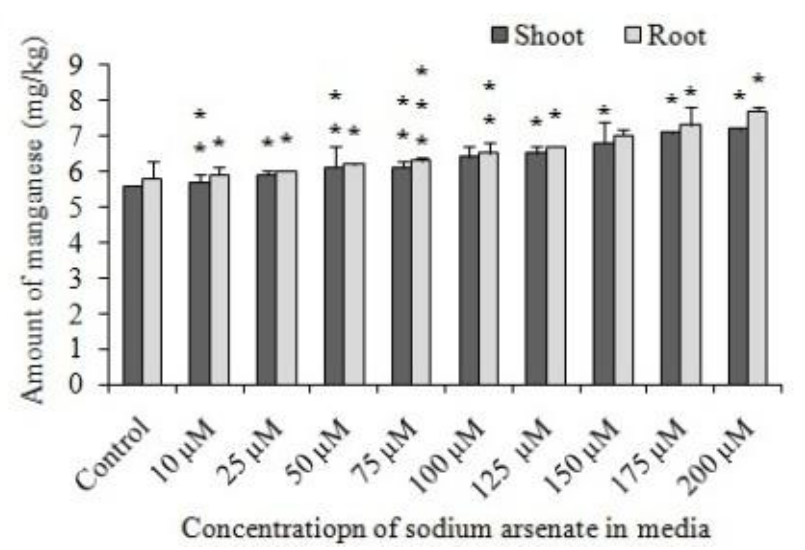

Fig 9b: Amount of manganese in $M$. charantia grown in different concentration of sodium arsenate in media in vitro.

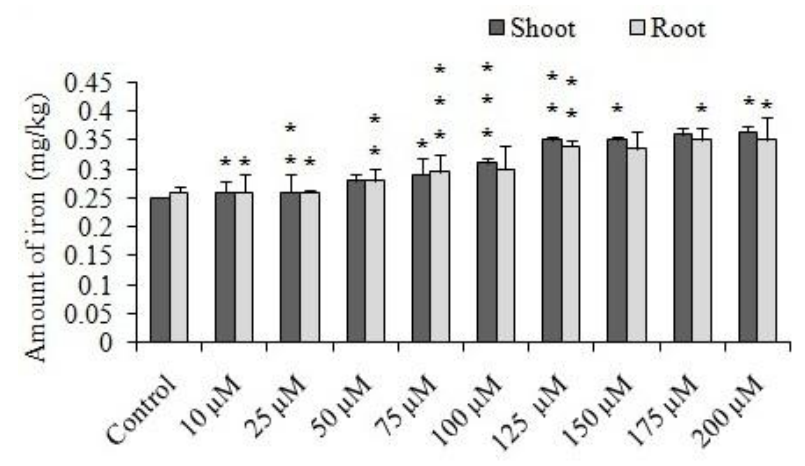

Sodium arsenate concentration in media

Fig 9c: Amount of iron in $M$. charantia grown in different concentration of sodium arsenate in media in vitro.

Concentrations of copper (Fig. 9d) and zinc (Fig. 9e) increased as the sodium arsenate concentration was increased in the test samples. We observed increase in copper concentration accompanied by increase in arsenic concentrations in seedlings but no such significant difference between root and shoot portion was found. Shoots of the seedlings contain more zinc than root. $19.7 \%$ increase of zinc content was found in highest treatment of arsenic $(200 \mu \mathrm{M})$ than untreated control. Result showed that there might be a synergistic effect between zinc and copper.

Arsenic concentration was found more in shoot than root. Highest arsenic uptake was found in $200 \mu \mathrm{M}$ sodium arsenate treated samples and the value was $1.35 \mathrm{mg} / \mathrm{kg}$ in case of shoot and $1.22 \mathrm{mg} / \mathrm{kg}$ in case of root (Fig. 9f). Concentration of cadmium (Fig. 9g) in root and shoot were decreased as the arsenic concentration increased in the tissue culture media. But concentration of cadmium in root and shoot portion in different doses of treatment was not showing any significance. 


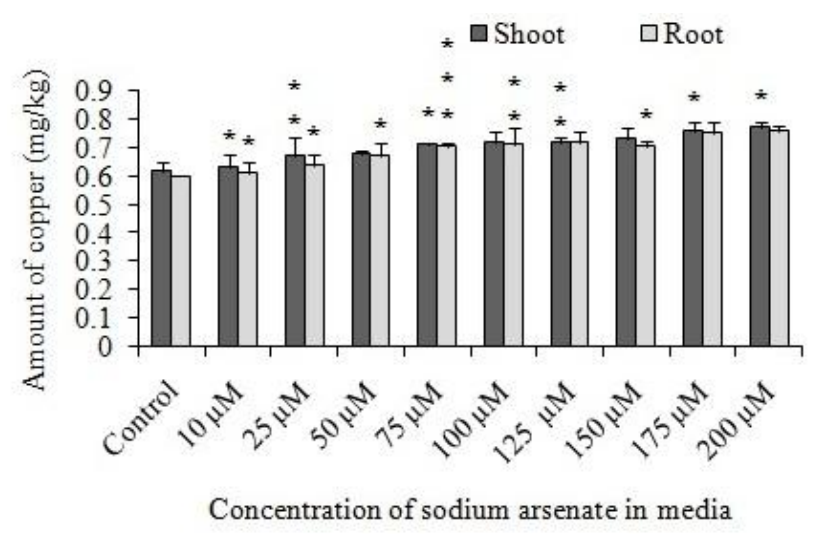

Fig 9d: Amount of copper in M. charantia grown in different concentration of sodium arsenate in media in vitro.

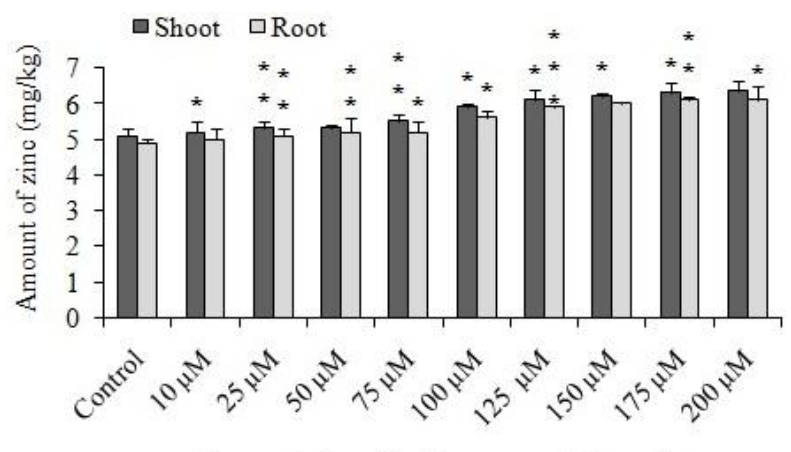

Concentration of sodium arsenate in media

Fig 9e: Amount of zinc in M. charantia grown in different concentration of sodium arsenate in media in vitro.

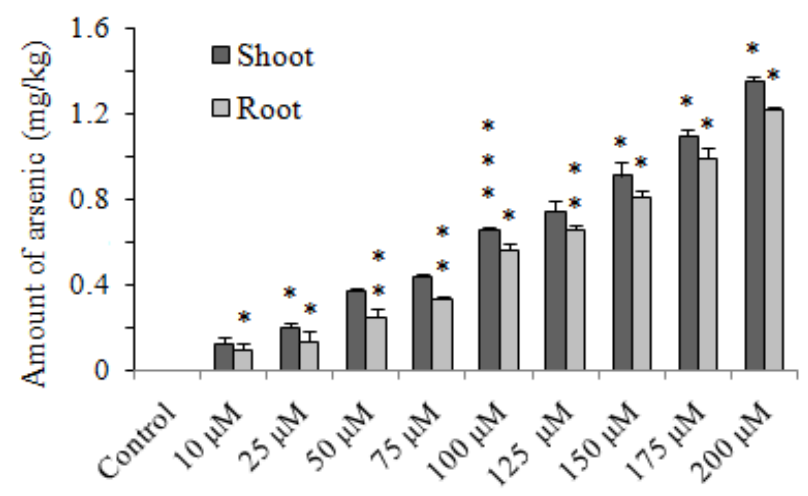

Sodium arsenate concentration in media

Fig 9f: Amount of arsenic in $M$. charantia grown in different concentration of sodium arsenate in media in vitro.

Concentrations of lead (Fig. 9h) in shoots of Momordica were decreased much up to $100 \mu \mathrm{M}$ sodium arsenate stress. Lowest value was found in $200 \mu \mathrm{M}$ sodium arsenate stress and the value was $0.29 \mathrm{mg} / \mathrm{kg}$ in case of shoot and $0.27 \mathrm{mg} / \mathrm{kg}$ in case of root samples. After arsenic exposure, anatomical changes were verified, mainly in the callus of $M$ charantia at different doses of arsenic. The damage worsened gradually as sodium arsenate dose in calli was increased. In case of higher doses of sodium arsenic treated samples we observed that cells were highly damaged.

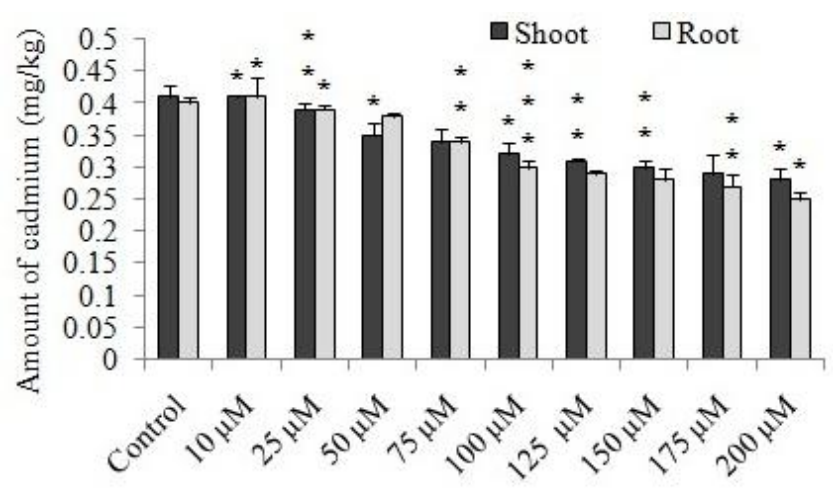

Concentration of sodium arsenate in media

Fig 9g: Amount of cadmium in M. charantia grown in different concentration of sodium arsenate in media in vitro.

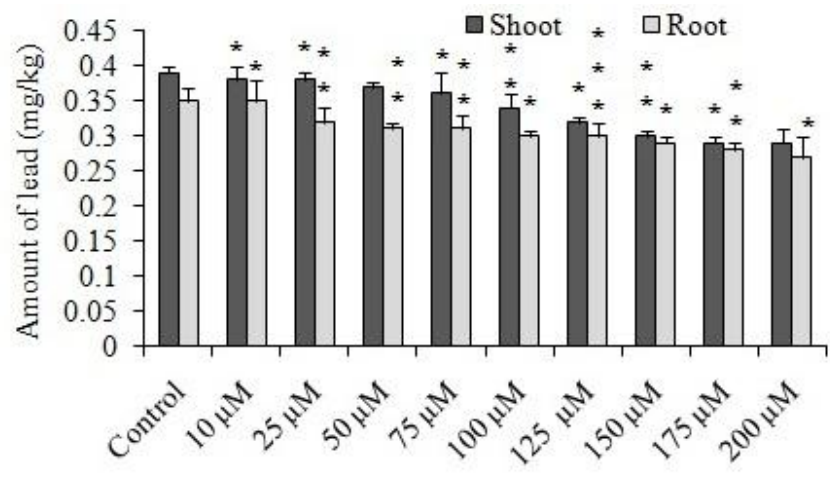

Concentration of sodium arsenate in media

Fig 9h: Amount of lead in M. charantia grown in different concentration of sodium arsenate in media in vitro.

Iron and $\mathrm{Mn}$ are constituents in a variety of enzymes (Mengel and Kirkby, 1987). The effect of As on dry weight likely limited demand for Fe and $\mathrm{Mn}$ in sensitive species. Mn concentrations tended to increase with increasing As exposure. However, As toxicity causes a breakdown in membrane stability (Cizewski Culotta et al., 2006) and a general changes in mineral uptake. Changes in root As seemed to affect transport of $\mathrm{Fe}$ from root to shoot. Zinc is used in a number of enzymes and functions similarly to $\mathrm{Mn}$ and $\mathrm{Mg}$ as an enzyme activator (Mengel and Kirkby, 1987). Arsenic induced to change the uptake of $\mathrm{Zn}$. Increased As exposure alters $\mathrm{Zn}$ translocation percent as well. Zinc is required for tryptophan synthesis as a precursor to the growth hormone auxin. Copper is used as a constituent in electron transport proteins and oxidation/reduction 
reactions (Mengel and Kirkby, 1987). Most notably, $\mathrm{Cu}$ is used to neutralize reactive oxygen species through $\mathrm{Cu} / \mathrm{Zn}$ superoxide dismutase $(\mathrm{Cu} / \mathrm{ZnSOD})$ (Benov and Fridovich, 1996). This enzyme protects the cell membrane from attack by superoxide radicals. Graham et al. (1987) reported that $\mathrm{Cu}$ usage in cellular functions in plant species may be very efficient. Low $\mathrm{Cu}$ status implies that $\mathrm{Cu}$ deficiency is one of the initial effects of As toxicity. Photosynthesis, respiration, lignification, and superoxide radical neutralization can all be compromised due to this interaction. Copper is a strong competitor with other metals for protein binding sites, however, very little free $\mathrm{Cu}$ is found in the cytoplasm (Finney and O'Halloran, 2003; Cizewski Culotta et al., 2006; Sheng et al., 2014).

$\mathrm{Mn}$ is one of the most important microelement and play major roles in plant tissue culture media. It is also involved in photosynthesis and respiration. Manganese is needed in plant system because it acts as an activator for some enzymes. It acts as an enzyme activator for nitrogen assimilation. It is essential for the manufacture of chlorophyll. Copper is a component of many important enzymes, which are involved in electron transport and protein and carbohydrate biosynthesis, thus it can be suggested that these enzymes might play a significant role in plant development and regeneration. Copper is involved as an enzyme activator and is thought to be involved in chlorophyll formation although its specific role is still unclear. It is also thought to be involved in protein synthesis. Copper catalyzes several plant processes. It has major function in photosynthesis and reproductive stages. It increases sugar content and improve flavor of fruits and vegetables. Zinc is essential component of more than 270 enzymes and is also responsible for stimulating growth of epidermal and epithelial cells (Kaplan et al., 2003). Plants require zinc because it activates some essential enzymes in plant systems. Zinc is necessary for chlorophyll production, carbohydrate and starch formation. It has an enzymatic system and seed formation. Zinc is an essential micronutrient for plants and is required in low concentrations to maintain life processes, in excess; this element causes toxicity in plants. This toxicity is caused by the role of $\mathrm{Zn}$ as a competitive inhibitor of other cofactors of metabolic pathways that are essential to plants, as in the case of $\mathrm{Fe}$, which is directly linked to redox reactions and may alter cell function, causing lower growth or breaks that hamper cell maintenance.
Iron is needed in plant systems for reaction involving in cell division and growth. Iron acts as an oxygen career and play a vital role in chlorophyll formation. Iron is an essential micronutrient that plays a unique role in metabolic processes. In plant, $\mathrm{Fe}$ is mainly used in chloroplast, mitochondria, and peroxisomes of plants for operating oxidation-reduction reaction.

\section{Conflict of interest statement}

Authors declare that they have no conflict of interest.

\section{Acknowledgement}

The first author is grateful to Indian Council of Medical Research (3/1/3/JRF/2010 dt. 01/09/2010) for award of Senior Research Fellowship to support this research.

\section{References}

Abedin, M.J., Feldmann, J., Meharg, A.A., 2002. Uptake kinetics of arsenic species in rice plants. Plant Physiol. 128, 1120-1128.

Alloways, B.J., 2008. Zinc in Soils and Crop Nutrition. International Zinc Association/International Fertilizer Industry Association, Brussels/Paris.

Bakare, R.I., Magbagbeola, O.A., Akinwande, A.I., Okunowo, O.W., 2010. Nutritional and chemical evaluation of Momordica charantia. J. Med. Plants Res. 4(21), 2189-2193.

Balasubramanian, G., Sarathi, M., Rajesh Kumar, S., Sahul Hameed, A.S., 2007. Screening the antiviral activity of Indian medicinal plants against white spot syndrome virus in shrimp. Aquaculture. 263, 15-19.

Benov, L., Fridovich, I., 1996. Functional Significance of the $\mathrm{Cu}, \mathrm{ZnSOD}$ in Escherichia coli. Arch. Biochem. Biophys. 327, 249-253.

Bhattacharya, P., Samal, A.C., Majumdar, J., Santra, S.C., 2009. Transfer of arsenic from groundwater and paddy soil to rice plant (Oryza sativa L.): A micro level study in West Bengal, India. World J. Agric. Sci. 5(4), 425-431.

Bhattacharya, S., Gupta, K., Debnath, S., Ghosh, U.C., Chattopadhyay, D.J., Mukhopadhyay, A., 2012. Arsenic bioaccumulation in rice and edible plants and subsequent transmission through food chain in Bengal basin: A review of the perspectives for environmental health. Toxicol. Environ. Chem. 94(3), 429-441.

Carbonell-Barrachina, A., Burló-Carbonell, F., Mataix- 
Beneyto, J., 1994. Effect of arsenite on the concentrations of micronutrients in tomato plants grown in hydroponic culture. J. Plant Nutr. 17, 1887-1903.

Chakraborti, D., Rahman, M.M., Paul, K., Chowdhury, U.K., Sengupta, M.K., Lodh, D., Chanda, C.R., Saha, K.C., Mukherjee, S.C., 2002, Arsenic calamity in the Indian subcontinent: What lessons have been learned? Talanta. 58, 3-22.

Cizewski Culotta, V., Yang, M., O’Halloran, T.V., 2006. Activation of superoxide dismutases: Putting the metal to the pedal. Biochim. Biophys. Acta. $1763,747-758$.

Cuypers, A., Remans, T., Weyens, N., Colpaert, J., Vassilev, A., Vangronsveld, J., 2013. Soil-plant relationships of heavy metals and metalloids. In: Heavy-Metals in Soils: Trace Metals and Metalloids in Soils and Their Bioavailability (Ed.: Alloway, B.J.). Springer Dordrecht Heidelberg, New York, London. pp.161-194.

Denyer, S.P., Hodges, N.A., Gorman, S.P., 2004. Bacterial resistance to antibiotics and clinical uses of antibacterial drugs. In: Hugo \& Russell's Pharmaceutical Microbiology. $5^{\text {th }}$ Edn. Blackwell Publishing. Chapt. (13-14). pp.220-250.

Finney, L.A., O'Halloran, T.V., 2003. Transition metal speciation in the cell: Insights from the chemistry of metal ion receptors. Science. 300, 931-936.

Graham, R.D., Ascher, J.S., Ellis, P.A.E., Shepherd, K.W., 1987. Transfer to wheat of the copper efficiency factor carried on rye chromosome Arm 5RL. Plant Soil. 99, 107-114.

Harpner, J., Breton, G., Harmon, A., 2004. Decoding $\mathrm{Ca}^{2+}$ signals through plant protein kinases. Annu. Rev. Plant Biol. 55, 263-288.

Hartmann, H.T., Kester, D.E., Davies, F.T., Geneve, R.L., 2002. Plant Propagation, Priciples and Practices. $7^{\text {th }}$ Edn. Prentice Hall, New Jersey.

Huang, R.Q., Gao, S.F., Wang, W.L., Stauton, S., Wang, G., 2006. Soil arsenic availability and the transfer of soil arsenic to crops in suburban areas in Fujian Province, southeast China. Sci. Total Environ. 368, 531-534.

Kaplan, L.A., Pesce, A.J., Kazmierczak, S.C., 2003. Clincal Chemistry-Theory, Analysis, Correlation. $4^{\text {th }}$ Edn. Mosby, London.

Katalin, S., 2011. Nutrient management. Chapter 2. Plant Nutrients. http://www.tankonyvtar. hu/en/tartalom/tamop425/0010_1A_Book_angol_02 tapanyaggazdalkodas/ch02.html

Malik, S., Zia, M., Rehman, R.U., Chaudhary, M.F.,
2007. In vitro plant regeneration from direct and indirect organogenesis of Momordica charantia. Pak. J. Biol. Sci. 10(22), 4118-4122.

Manye, Y., Zhao, M., Lan, L., Chen, F., 2004. Establishment of in vitro regeneration system of bitter melon (Momordica charantia L.). High Technol. Lett. 10, 44-48.

Marin, A.R., Masscheleyn, P.H., Patrick, W.H., 1993. Soil redox-pH stability of arsenic species and its influence on arsenic uptake by rice. Plant Soil. 152, 245-253.

Marschner, H., 1995. Mineral Nutrition of Higher Plants. Academic Press, London.

Meharg, A.A., Rahman, M.M., 2003. Arsenic contamination in Bangladesh paddy field soils: implication for rice contribution to arsenic consumption. Environ. Sci. Technol. 37, 229-234.

Mengel, K., Kirkby, E.A., 1987. Principals of Plant Nutrition. International Potash Institute, Worblaufen -Bern.

Milner, M.J., Seamon, J., Craft, E., Kochian, L.V., 2013. Transport properties of members of the ZIP family in plants and their role in $\mathrm{Zn}$ and Mn homeostasis. J. Exp. Bot. 64, 369-381.

Paschen, W., 2003. Mechanisms of neuronal cell death: Diverse roles of calcium in the various subcellular compartments. Cell Calcium. 34, 305-310.

Paul, A., Raychaudhuri, S.S., 2010. Medicinal uses and molecular identification of two Momordica charantia varieties - A review. eJ. Biol. 6(2), 43-51.

Prasad, V., Jain, V., Girish, D., Dorle, A.K., 2006. Wound-healing property of Momordica charantia L. fruit powder. J. Herb. Pharmacother. 6(3-4), 105115.

Rahman, M.A., Hasegawa, H., Rahman, M.M., Rahman, M.A., Miah, M.A., 2007. Accumulation of arsenic in tissues of rice plant (Oryza sativa L.) and its distribution in fractions of rice grain. Chemosphere. 69, 942-948.

Santos, K.K., Matias, E.F., Sobral-Souza, C.E., Tintino, S.R., Morais-Braga, M.F., Guedes, G.M., Santos, F.A., Sousa, A.C., Rolón, M., Vega, C., de Arias, A.R., Costa, J.G., Menezes, I.R., Coutinho, H.D., 2012. Trypanocide, cytotoxic, and antifungal activities of Momordica charantia. Pharm. Biol. 50(2), 162-166.

Schaefer, H., Renner, S.S., 2010. A three-genome phylogeny of Momordica (Cucurbitaceae) suggests seven returns from dioecy to monoecy and recent long-distance dispersal to Asia. Mol. Phylo. Evol. 54, 553-560. 
Sheng, Y., Abreu, I.A., Cabelli, D.E., Maroney, M.J., Miller, A.F., Teixeira, M., Valentine, S. J., 2014. Superoxide dismutases and superoxide reductases. Chem. Rev. 114, 3854-3918.

Singh, N., Ma, L.Q., Srivastava, M., Rathinasabapathi, B., 2006. Metabolic adaptations to arsenic-induced oxidative stress in Pteris vittata $\mathrm{L}$ and Pteris ensiformis L. Plant Sci. 170, 274-282.

Sultana, R.S., Bari Miah, M.A., 2003. In vitro propagation of karalla (Momordica charantia Linn.) from nodal segment and shoot tip. J. Biol. Sci. 3, 1134-1139.

Tanaka, H., Toyama, J., Akashi, R., 2009. Molecular characterization of a galactose-binding lectin from
Momordica charantia seeds and its expression in tobacco cells. Asian J. Plant Sci. 8(8), 544-550.

Thiruvengadam, M., Rekha, K.T., Yang, C.H., Jayabalan, N., Chang, M., 2010. High frequency shoot regeneration from leaf explants through organogenesis in bitter melon (Momordica charantia L.). Plant Biotech. Rep. 4(4), 321-328.

Toyama, J., Tanaka, H., Horie, A., Uvchiyama, T., Akashi, R., 2008. Purification and characterization of anti-H lectin from the seed of Momordica charantia and the inter-specific differences of hemagglutinating activity in Cucurbitaceae. Asian J. Plant Sci. 7(7), 647-653.

\section{How to cite this article:}

Ray, S. K., Raychaudhuri, S. S., 2017. Effect of sodium arsenate on Momordica charantia L. seeds in vitro. Int. J. Curr. Res. Biosci. Plant Biol. 4(6), 51-61. doi: https://doi.org/10.20546/ijcrbp.2017.406.006 